\title{
SOX10 wt Allele
}

National Cancer Institute

\section{Source}

National Cancer Institute. SOX10 wt Allele. NCI Thesaurus. Code C102892.

Human SOX10 wild-type allele is located in the vicinity of 22 q13.1 and is approximately 17 $\mathrm{kb}$ in length. This allele, which encodes transcription factor SOX-10 protein, plays a role in transcriptional activation. Mutation of the gene is associated with Waardenburg syndrome types $2 \mathrm{E}$ and $4 \mathrm{C}$ and with peripheral demyelinating neuropathy, central dysmyelinating leukodystrophy, Waardenburg syndrome, and Hirschsprung disease. 